J. Elman, E. Bates, M. Johnson,

A. Karmiloff-Smith, D. Parisi, K. Plunkett 著 乾 敏郎，今井むつみ，山下博志 訳

\section{認知発達と生得性 一心はどこから来るのか一}

Rethinking Innateness

-A connectionist perspective on development-

(共立出版，1998 年刊，7,500 円（税別）, ISBN 4-320-02901-1)

「知識はどこから来るのか」という問いを最初に置 いたまえがきで始まる本書は，一言でいえば，ニュー ラルネットと脳科学の視点で見た認知発達研究の可能 性について論じた本である、人間は，あるいは脳は， Nature（生まれ）と Nurture（育ち）の組み合わせ で認知的な機能を発達させ, 基本的な事物の認知から 高次の思考・言語までの幅広い能力をもつことは, 我々もよく知っている. その能力の獲得機構について は, 従来より幼児発達のヒアジェ, 文法獲得のチョム スキーといった大家の理論があり，最近の研究はこれ ら大家の理論をいかに実現するか，あるいは越えるか という流れで行われてきているといっても過言ではな い.

ところが，ニューラルネットや脳研究の分野の人が 認知発達を勉強してみると, それらの理論には発達を 実際に担っている脳のメカニズムについての議論が少 ないことに気がつかれるであろう。むしろ本書では， 知識は遺伝的に組み込まれているという考え方が言語 の分野などに根強くあると，指摘している。しかし， 我々は日本語の文法や知識をもって生まれてくるはず がない。このような誤解を解き, 認知発達に正しい （?）脳メカニズム（具体的には遺伝子発現，ニューラ ルネットの広義の計算理論とダイナミクス）の議論を もち込んで，その視点のもとで生まれと育ちの関係を 理解していこう，というのが本書のねらいである。 その具体的な内容は，各章で以下のようになってい る.

一章 認知発達への新たなアプローチ

認知発達を脳研究とコネクショニストの視点で研究 するという問題設定について述べている。
二章 なぜコネクショニズムか

ニューラルネットとはどういうもので, 学習とは何 をすることか，ということを説明している．特に，二 ューラルネットはまったくの白紙からの学習ができる という意見について，実際の学習はネットワークの学 習能力・構造などに制約される面が多く，誤解がある と述べている.

三章 個体発生的発達：コネクショニストによる統 合

例えば言語発達における語彙の獲得や文法の段階的 な獲得など，これまでに提案されているコネクショニ ストモデルによる認知機能獲得について説明してい る、また，なぜこれが認知発達のモデルとなりうるの か, ある範囲内での学習性が本質, といった議論がな されている.

四章 変化の形態

ニューラルネットの活動と学習のダイナミクスにつ いて解説している．また，パラメー夕の微妙な変化で もシステムの振る舞いは劇的に変わりうることを説明 している.

五章 脳の発達

脳の発達・可塑性と機能の再構成・臨床例など, 認 知発達に関連した神経科学の研究についての紹介とな っている.

六章 相互作用，あらゆるレベルで

ひよこの刷り込み現象のコネクショニストモデルを 例に取り，学習における時間・順序の重要性（例えば 簡単なことから順番に学習する）について述べてい る.また，早い学習と遅い学習の違いについて考察 し，多数の機能の相互作用を取り込んでより広範な機 能を獲得するには，遅い学習の方が有利であると述心゙ ている。

七章 生得性を考える

ここまでの議論を踏まえて, 改めて「知識はどこか ら来るのか」という問題に取り組む。脳における記憶 の実体であるコネクション（記憶内容）と，その記憶 を獲得するメカニズム (学習機構) は別であると説明 し, 先天的にもって生まれてくるのは内容ではなく, 知識を獲得する学習性であると論じている。そして， 環境と学習システムの相互作用によって人間の各種機 能が必然的にできあがってくる，という描像を述べ て，今後はこのような先天的なメカ二ズムと後天的な 環境の影響についてより深い研究が必要としている。

以上の全体を通じて, 評者の意見は以下のようなも のである。

本書で述べている個別のモデルや議論についてはあ 
やしいと感じるところも多々あるが，認知発達を脳科 学とニューラルネットの立場から考えていくという研 究の方向性はまちがっていない，その流れの延長に， 幼児発達や文法獲得などを通してのより深い人間の 「知」の理解と実現があるであろう。その意味で，本 書は知能や発達に興味のある方にはお勧めの一冊であ る. 可能性としては未知数だが，目の前に参加可能な 研究領域が広がっている感じである。しかし, 関連す る研究分野は幅広く，その全体像の理解は容易ではな い. 本書はその領域全体の一部について述べているに 過ぎない. 本書にも 33 ページに及ぶ文献りストがつ いているが, それが逆に学習の大変さを表現している ように思える。

最後に認知発達の工学的な意味について. 現在の二 ューラルネットは, 入出力関係の学習と汎化により, 一見して知的な動作を実現できる。しかし実際には， その動作は入出力関係の実現であって，本当にものを 理解して動作しているとは言い難い.またより広く考 えて, 各種の工学的なパターン認識の技術や記号的な 推論技法は，現場ではなかなか使われていない。これ らの機能はいずれも脳システムではその発達の比較的 早い段階で獲得され，適切に使用されて高次の知能が 実現されていく核となっている.人間の認知発達の初 期段階では，個々の工学的な要素技術と脳の部分機能 との違いがそれほど大きいとは思えない.この段階で 認知発達に注目することは, 現在の工学と脳システム の根本的な違いに迫れる可能性がある。

(東京農工大学 大森 隆司)

石井健一郎，上田修功，前田英作，村瀬 洋 共著

\section{わかりやすいパターン認識}

$$
\text { （オーム社，1998 年 } 8 \text { 月刊，204 頁） }
$$

パターン認識の研究は, コンピュータが登場して間 もない頃に始まり，1950１960 年代に隆盛を極め， その時代に, 識別・学習理論などの基本的な枠組みの ほとんどが築かれたと言っても過言ではない。その 後, コンピュータの性能が飛躍的に向上した 1970１980 年代には，文字読み取り装置などの実用 的なパターン認識装置の開発研究に興味が移り, 個別 の認識課題のためのさまざまな特徴抽出法が考案され た. 特徵抽出は認識対象に依存することが多く, 認識 装置の性能を上げるためには多くのヒューリスチック スを組み込む必要があり, 認識対象ごとに特徴抽出法
を工夫することがパターン認識の本質だと考える風潮 すらあった.さらに，1980 年代の後半に始まった第 二次ニューロブームでは, ニューラルネットを用いれ ば識別・学習の問題は簡単に解決でき, パターン認識 理論はもはや学ぶに值しない古典的な学問であるとい うような誤った見方すらあった。このような状況を憂 い, パターン認識を正しく理解し，その重要性を再認 識してもらいたいとの思いを込めて書かれたのが本書 である、最近では, ニューロブームの反動からか, 逆 に, 応用研究が軽視され, 確率統計的な手法やモデル の解析に重点が移っているように感じるが, この分野 の健全な発展のためには両者のバランスが重要であろ う.そういう意味で, 長年実用的なパターン認識手法 の開発にかかわってきた著者らが, 統計的パターン認 識について，根底に流れる重要な概念と現場で役立つ 項目にしぼって, 初心者が独学で学べるようにわかり やすく書かれた本書の意義は大きい.

第 1 章では, パターン認識とは, 観測されたパター ンをあらかじめ定められた複数の概念のうちの一つに 対応させる処理であり，そのためには，元のパターン から識別に有効な本質的な特徵のみを抽出する特徵抽 出と, 入力パターンをあらかじめ用意された識別辞書 と照合して，複数のクラスのうちの一つを対応させる 識別が必要であることが述べられている，また，最も 基本的な識別方式として，入力パターンを最も近いプ ロトタイプの属するクラスに識別する最近傍決定則 (nearest neighbor rule) が紹介されている.

第 2 章では, 特徴空間内でプロトタイプの位置を学 習サンプルから自動的に求めるためには, 識別関数の 学習が重要であることが述べられている。線形識別関 数と最近傍決定則との関係に始まり，パーセプトロン の学習, 区分的線形識別関数について触れられてい る.また, 第 3 章では, Widrow-Hoff の学習規則, 階層型ニューラルネットのための誤差逆伝播法が説明 されている.

第 4 章は, 識別器の設計を扱っているが，ここで, やっと確率やパラメー夕推定の話題が登場する. 次元 の呪いや過学習についても触れられ，その対処方法と して, 情報量規準, 交差確認法, ブートストラップ法 などについても解説されている. 第 4 章までの構成 は, 従来のパターン認識の教科書の構成とは異なり, パターン認識系を設計する際の実用性を重視した形を 取っている，確率統計にあまり詳しくない読者にとっ ては，わかりやすいのではないかと思う。

第 5 章では，特徵の評価の問題が扱われ，特徴空間 上での分布の重なりの度合いを表すべイズ誤り確率が 